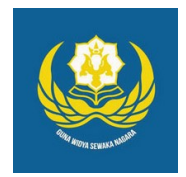

Jurnal Analogi Hukum

Journal Homepage: https://ejournal.warmadewa.ac.id/index.php/analogihukum

\title{
Tanggung Jawab Bank Terhadap Nasabah Atas Berkurangnya Dana Akibat Skimming Dalam Rekening Bank
}

\author{
Kadek Ayu Manik Gita Shintadewi*, I Nyoman Putu Budiartha dan I Made Minggu Widyantara \\ Fakultas Hukum, Universitas Warmadewa, Denpasar, Bali-Indonesia \\ *gitashintadewi@yahoo.co.id
}

\begin{abstract}
How To Cite:
Shintadewi, K. A. M. G., Budiartha, I. N. P., \& Widyantara, I. M. M. (2021). Tanggung Jawab Bank Terhadap Nasabah Atas Berkurangnya Dana Akibat Skimming Dalam Rekening Bank. Jurnal Analogi Hukum. 3(2). 206-209. Doi: https://doi.org/10.22225/ ah.3.2.2021.206-209
\end{abstract}

\begin{abstract}
The progress of the banking system cannot be separated from the role of information technology. A crime related to banking that is currently being discussed is Skimming Skimming, which was carried out by stealing customer data stored in a magnetic strip on an ATM card and transmitted wirelessly. and 2 problem formulations, namely 1. How the bank's responsibility to customers for reduced funds due to skimming in bank accounts?2. What the process carried out by banks and customers for reduced funds due to skimming in bank accounts?type of research is normative legal research, the approach method is legislation, legal material collection techniques are to study, study and process legal material. The results of the study state that the bank as a business actor in the form of a legal entity is responsible for providing compensation for losses from consumers, namely customers due to service products provided, namely e-banking services through electronic media,efforts made by banks and customers for reduced funds due to skimming. the bank can tighten the security when transactions are carried out, especially at ATMs, for customers if they experience a skimming incident, they should immediately report it to the bank.
\end{abstract}

Keywords: Responsibility; Reduction of Funds; Skimming.

\begin{abstract}
Abstrak-Majunya sistem perbankan tidak bisa dipisahkan dengan peran teknologi informasi. Kejahatan terkait perbankan yang hangat dibicarakan adalah Skimming. Skimming dilaksanakan lewat mekanisme curian data nasabah yang disimpan pada magnetik strip pada kartu ATM lalu dikirim lewat nira kabel. Skripsi ini mengangkat 2 rumusan masalah yaitu 1. Bagaimanakah tanggung jawab bank terhadap nasabah atas berkurangnya dana akibat skimming dalam rekening Bank?, 2. Bagaimanakah proses yang dilakukan pihak bank dan nasabah atas berkurangnya dana akibat skimming dalam rekening Bank? Tipe penelitian yang digunakan adalah penelitian hukum normatif, metode pendekatan yang digunakan adalah perundangundangan, teknik pengumpulan bahan hukum dikaji, ditelaah dan diolah literatur, peraturan perundanganundangan, artikel- artikel atau tulisan yang berkaitan dengan permasalahan yang akan diteliti. Hasil Penelitian menyatakan bahwa bank sebagai pelaku usaha yang berbentuk badan hukum bertanggung jawab memberikan ganti rugi atas kerugian dari konsumennya yakni nasabahnya akibat produk jasa yang diberikan, yaitu pelayanan e-banking melalui media elektronik, upaya yang dilakukan pihak bank dan nasabah atas berkurangnya dana akibat skimming dalam bank adalah pihak bank dapat memperketat keamanan saat transaksi dilakukan khususnya di ATM, dan untuk nasabah jika mengalami kejadian berupa skimming agar segera melaporkan ke pihak bank.
\end{abstract}

Kata Kunci: Tanggung jawab; Berkurangnya Dana; Skimming

\section{Pendahuluan}

Selaku negara hukum, di indonesia memang seharusnya mengatur bagian-bagian kehidupan antar warga yang satu dengan yang lainya, Karena permasalah hukum akan dihadapi oleh setiap orang. Perlu diketahui jika tiap aturan hukum berakar atau bertumpu pada asas hukum, yaitu suatu nilai yang dipercaya bertepatan dengan penataan masyarakat guna tercapainya ketertiban yang berkeadilan (Atmadja \& Budiartha, 2019).

Dengan berkembangnya zaman dan makin 
hebatnya teknologi, Kejahatan baru bermunculan seperti siber (Cyber Crime) maka dari itu pentingnya adanya teknologi informasi di segala sektor tanpa terkecuali di dunia bank. majunya sistem perbankan tak bisa dipisah dengan peran teknologi informasi. Makin maju dan lengkap pelayanan yang dipakai perbankan buat mempermudah layanan, makin bervariasi dan lengkap juga teknologi yang bank punya. Selain mempermudah kegiatan dalam perusahaan, alat teknologi punya tujuan yaitu melancarkan layanan untuk nasabah bank. Seluruh produk yang ditawarkan pada nasabah tidak begitu berbeda, maka dari itu persaingan yang terjadi pada perbankan adalah gimana cara memberi produk yang mudah serta cepat. Kegiatan perbankan yaitu electronic transaction (e-banking) lewat mesin ATM, HP (phone banking) serta jaringan internet (Internet banking), adalah sebagian jenis layanan transaksi perbankan lewat teknologi informasi. memakai teknologi bisa melindungi amannya data maupun transaksi.

Kejahatan yang ada hubungannya dengan perbankan dan masih banyak diperbincangkan adalah Skimming, modus operasi pembobolan bank menggunakan trik Skimming dengan cara dicurinya data nasabah yang disimpan pada magnetik strip di kartu ATM lalu dikirim secara nirkabel (Ishaq, 2009)

Ada beberapa langkah yang dipergunakan untuk kejahatan jenis ini, yang pertama pelaku memasang alat skimmer di mulut mesin ATM, kemudian dipasangkannya kamera tersembunyi untuk mendapatkan gerakan jari nasabah disaat menekan pin, pelaku juga mengkondisikan agar seolah-olah kertas yang keluar mengisyaratkan bahwa uang di mesin telah habis, lalu setelahnya pelaku akan memperoleh data nasabah lalu menjualnya ke kartu palsu.

Pelaku Skimming saat ini tidak usah memakai kamera tersembunyi atau di intip lewat bahu belakang orang, tapi bisa dengan keypad tidak asli di mesin ATM, fungsinya pin nasabah direkam dengan otomatis. Tidak lepas dari cara curang operasi yang dilakukan, perbuatan Skimming untuk dapat pin ATM di ujungnya akan disertai dengan dipindahkannya data yang didapat dalam kartu ATM palsu. Kartu ATM palsu itu lalu dipakai untuk mengambil uang di mesin ATM. Mesin ATM yang kerjanya lewat satu jaringan internet, demikian ditariknya ataupun dipindah (Transfer) dana yakni bebannya pada simpanan nasabah lalu secara otomatis akan dilakukannya serta dikurangi jumlah simpanan nasabah pada bank lewat ATM
Pada satu sisi teknologi informasi memberi manfaat dan tidak sedikit pada peningkatan serta sejahteranya peradaban manusia serta pelayanan publik ataupun internal meningkat. Pada sisi lainnya teknologi informasi dipakai oleh seorang yang tidak tanggung jawab dengan dilakukan perbuatan yang sifatnya melawan hukum, serta menyerang semua kepentingan hukum masyarakat maupun negara

\section{Rumusan Masalah}

1. Bagaimanakah tanggung jawab bank terhadap nasabah atas berkurangnya dana akibat skimming dalam rekening Bank ?

2. Bagaimanakah proses yang dilakukan pihak bank dan nasabah atas berkurangnya dana akibat skimming dalam rekening Bank ?

\section{Metode}

Penelitian normatif ialah penelitian yang kajiannya ialah studi dokumen, digunakannya berbagai data sekunder contohnya aturan perundang-undangan , teori hukum, putusan pengadilan, maupun pendapat para ahli. Penelitian ini jenisnya terapan analisis kualitatif yaitu dijelaskannya data yang ada kata maupun pernyataan bukan dengan angka-angka. Digunakannya pendekatan permasalahan yaitu a. perundangan dengan menelaah seluruh aturan perundangan maupun regulasi yang ada sangkutannya pada isu hukum yang masih ditangani, b. pendekatan kasus pada pembuatan serta pemecahan masalah pada penelitian ini.

Sumber Bahan Hukumnya adalah Bahan hukum primer, yang mana bahan sumber bahannya sudah teratur serta sifatnya mengikat, Bahan Hukum Sekunder, tentu diberikannya penjelasan terhadap bahan dimana asalnya dari bahan hukum primer, Bahan hukum tersier, adalah penopang diluar 2 bahan hukum diatas misal kamus, ensiklopedia yang ada kaitan di penelitian ini.

Bahan Hukumnya dikumpul dengan mengkaji, menelaah serta mengolah baik bahan hukum primer, sekunder dan tersier seperti literatur, peraturan perundangan, artikel ataupun tulisan yang ada kaitan di permasalahan yang akan diteliti.

\section{Hasil dan Pembahasan}

\section{Perlindungan Hukum Terhadap Nasabah Atas Berkurangnya Dana Akibat Skimming Dalam Rekening Bank}

Salah satu cara bertindak maupun berbuat hukum pemerintah dan diberi pada subjek 
Tanggung Jawab Bank Terhadap Nasabah Atas Berkurangnya Dana Akibat Skimming Dalam Rekening Bank

hukum sebanding pada hak dan kewajiban yang dilakukan atas dasar hukum positif di Indonesia disebut perlindungan hukum yang muncul akibat ada sebuah hubungan hukum. Hubungan hukum adalah terlibatnya antar subjek hukum yang mempunyai hubungan hukum maupun memiliki akibat hukum (Soeroso, 2006).

Philipus M. Hadjon, menentukan jika perlindungan hukum dibagi jadi dua, antara lain perlindungan hukum represif dan perlindungan hukum preventif. (Hadjon, 1987).

Muchsin mengemukakan jika perlindungan hukum ialah sebuah hal yang dilindunginya ilalah subyek hukum lewat aturan perundangan yang berlaku serta tpenerapannya dipaksa dengan sebuah sanksi (Muchsin, 2003).

Menurut Pasal 1 angka 5 UU No. 10 Tahun 1998 hubungan antara bank dan nasabah penyimpan dana ada dua hubungan, ialah Dasar hubungan ialah pada rasa percaya dan Dasarnya pada perjanjian penyimpanan.

Hubungan hukum antara bank serta nasabah penyimpan dana maupun nasabah debitur atas dasarnya perjanjian. demikianlah hubungan antar bank serta nasabah di dasar atas hubungan percaya dan hubungan hukum. Dengan kata lain, bank sebagai pelaku usaha yang berbentuk badan hukum bertanggung jawab memberikan ganti rugi atas kerugian dari konsumennya yakni nasabahnya akibat produk jasa yang diberikan, yaitu pelayanan e-banking melalui media elektronik. Bentuk ganti rugi dijelaskan dalam ayat (2), di mana dapat berupa pengembalian uang yang sejenis atau setara nilainya.

Jika nantinya ada unsur kealpaan pada nasabah dalam menjaga rahasia PIN, Misalnya saat nasabah sedang melakukan transaksi di mesin ATM, tapi dia lupa menutup keyboard yang ditekan, atau saat dia tekan tombol tapi bisa dilihat orang di belakangnya, dan membuktikan lewat CCTV yang terekam, maka itu tidak bisa bikin pihak bank untuk ganti rugi jika saldonya rekeningnya dicuri, jadi semuanya tergantung pada nasabah dalam menjaga rahasia PIN. Namun jika nasabah telah punya usaha untuk menutup keyboard mesinnya saat dilakukannya transaksi , tapi nyatanya tetap saja alat lainnya yang di pasang di mesin itu di luar mamunya nasabah pada pengurangan resiko bocornya PIN secara ketentuan dia tidak berbuat salah, dia telah tutup keyboard, dan buktinya rekaman CCTV, lalu bank harus tanggung jawab lewat memberi ganti rugi.
Upaya Yang Dilakukan Pihak Bank Dan Nasabah Atas Berukurangnya Dana Akibat Skimming Dalam Rekening Bank

Upaya pencegahan yang dilakukan oleh pihak bank ATM

1. Melindungi tombol angka di mesin

2. Pasang alat anti skimmer dan optimalkan CCTV pada semua mesin ATM

3. Pasang peringatan untuk nasabah supaya berhati-hati jika ada kegiatan transaksi di mesin ATM serta dilakukannya cek berkala keadaan mesinnya serta ruang ATM.

\section{Terapkan teknologi chip.}

Permasalahan yang menimpa antar bank dan nasabahnya saat prakteknya akan dilaksanakan lewat cara penyelesaian tingkatan internal. Di awal Jika ada masalah yang terjadi dengan bank dan nasabah nanti makan selesainya di internal saja. Pertama nasabah melakukan pengaduan atas masalahnya itu pada bank, lalu bank akan meneliti dan diperiksanya masalah itu serta diberikan solusi karena masalah tersebut, pada penyelesaian masalah kartu ATM antar bank dan nasabah, ada cara yang dapat ditempuh yaitu

\section{Negosiasi}

tawar menawar terjadi saat negosiasi untuk didapatkan keputusan, seperti pilihan terbaik agar sengketa bisa selesai. Usaha untuk dicapainya kompromi atau damai serta untungnya semua pihak yang bersengketa, yang awalnya punya kepentingan berlawanan lewat satu proses penawaran itulah negosiasi. Dan alternatif penyelesaian sengketa bank.

\section{Mediasi Perbankan}

Diselesaikannya dengan aduan masalah lewat mediasi perbankan sama seperti aturan Bank Indonesia Nomor 10/1/PBI/2008 tanggal 29 januari 2008 yang menjelaskan tentang mediasi perbankan.

\section{Simpulan}

Berdasarkan hasil penjelasan diatas, maka simpulan yang bisa diangkat pada penelitian ini adalah

Upaya hukum yang bisa ditempuh pihak nasabah saat terjadi kerugian terhadap musnahnya dana simpanan pasal 19 ayat (1),(3) undang-undang perlindungan konsumen, jika merasa rugi bisa tuntut secara langsung ganti ruginya pada produsen lalu produsen harusnya 
memberi balasan atau selesainya dengan jarak waktunya 7 hari sesudah transaksi terjadi serta semua konsumen yang rugi bisa menggugat pelaku usaha lewat lembaga yang tugasnya menyelesaikan sengketa antara konsumen dan pelaku usahanya maupun lewat peradilan umum ataupun penyelesaian sengketa konsumen bisa ditempuh lewat pengadilan dasarnya UUPK pasal 45 ayat (1) ataupun di luar pengadilan atas dasar pilihan sukarela antar pihak dasarnya UUPK pasal 45 ayat (2)

Langkah tindak skimming yang dilaksanakan oleh pihak bank seperti klarifikasi aduan nasabah yang dananya hilang. Caranya ialah dilakukan cek data rekening nasabah agar tahu penyebab transaksi serta saldo berkurang, lalu disampaikannya oleh nasabah jika merasa ganjil. Hasil dari pengecekan itu akan diketahui serta disimpulkan apakah transaksi itu sah ataupun tidak. Di akhir akan dibuatnya laporan tindak pidana penggandaan kartu ATM di kepolisian. Lalu usaha pencegahan yang diperbuat oleh pihak bank ialah dipasangnya penutup pelindung keypad atau tombol angka di mesin ATM supaya tidak nampak kode angka saat nasabah tekan, serta dipasangnya alat anti skimmer serta dioptimalkan operasi CCTV di semua ATM.

\section{Daftar Pustaka}

Atmadja, I. D. G., \& Budiartha, I. N. P. (2019). Sistematika Filsafat Hukum. Malang: Setra Press.

Ishaq. (2009). Dasar-dasar Ilmu Hukum. Jakarta: Sinar Grafika.

Soeroso. (2006). Pengahantar Ilmu Hukum, Cetakan Kedelapan. Jakarta: Penerbit Sinar Grafika.

Hadjon, P. M. (1987). Perlindungan Hukum Bagi Rakyat di Indonesia. Surabaya: PT. Bina Ilmu.

Muchsin. (2003). Perlindungan dan Kepastian Hukum bagi Investor di Indonesia. Magister Ilmu Hukum Program Pascasarjana Universitas Sebelas Maret, Surakarta. 